\title{
Use of the conjugate of disulphated ursodeoxycholic acid with $p$-aminobenzoic acid for the detection of intestinal bacteria
}

\author{
M Takahashi, T Konishi, Y Maeda, Y Matsugu, F Akazawa, T Eto, M Okajima, K Uchida, \\ Y Masaoka, K Okada
}

\begin{abstract}
The disulphate ester of ursodeoxycholyl- $p$ aminobenzoic acid (PABA-UDCA) was synthesised and compared with PABA-UDCA for its use in detection of intestinal bacteria. This compound, PABA-UDCA disulphate, had characters in common with PABA-UDCA in that it was deconjugated by cholylglycine hydrolase to release free PABA and bacteria that split glycocholic acid deconjugated PABA-UDCA disulphate. Further, in rat experiments urinary excretions of PABA were measured for six hours after oral administration of $15 \mathrm{mg}$ PABA-UDCA disulphate. Ten control rats excreted (mean (SE) 188.2 (13.6) $\mu \mathrm{g}$ of PABA; 10 rats with an intestinal stagnant loop excreted more $(530.1 \quad(30 \cdot 1) \mu g$; $p<0.001$ ): whereas 10 rats in each of three groups pretreated by oral administration of various antibiotics excreted less (polymixin B+tinidazole, 4.9 (1.6) $\mu \mathrm{g}$; kanamycin, 31.0 (4.7) $\mu \mathrm{g}$; clindamycin 40.9 (5.5) $\mu \mathrm{g} ; \mathrm{p}<0.001$ ). By contrast with PABA-UDCA, PABA-UDCA disulphate was not actively absorbed from any part of the small intestine in everted gut sac experiments, and showed poor recovery from bile after its intraileal instillation in rats. This indicated that PABA-UDCA disulphate is a single pass type substance in the gut and its oral administration test reflects the sum of the activities of bacteria in the small intestine and colon. The disulphate was easily soluble in water and this allowed its application in an in vitro test involving PABA-UDCA disulphate incubation with intraperitoneal pus (PABAUDCA disulphate incubation test) from patients with peritonitis. This test was carried out on six patients with peritonitis, and the severity of bacterial peritonitis was expressed quantitatively. From the results obtained PABA-UDCA disulphate was considered a good material to detect intestinal bacteria. (Gut 1993; 34: 823-828)
\end{abstract}

To evaluate intestinal bacteria, clinical application of breath tests with ${ }^{14} \mathrm{C}$ labelled glycocholate, ${ }^{14} \mathrm{C}$-D-xylose, glucose- $\mathrm{H}_{2}$, or lactulose $\mathrm{H}_{2}$ has been proposed. ${ }^{1-7}$ These tests have flaws, however, because they need a radioisotopic material or special, expensive equipment for measurement. To solve these problems, we reported the use of a conjugate of ursodeoxycholic acid with $p$-aminobenzoic acid (PABAUDCA) for the evaluation of intestinal microflora. ${ }^{89}$

In this article we report studies on the use of a disulphated derivative of PABA-UDCA for the detection of intestinal bacteria.

\section{Materials and methods}

SYNTHESIS OF THE PABA CONJUGATE OF UDCA DISULPHATE

Synthesis of PABA-UDCA was by the method described previously.$^{8}$ The disulphate ester of PABA-UDCA was prepared by a modification of the method of Goto and associates. ${ }^{10}$ To a solution of PABA-UDCA $(1.0 \mathrm{~g})$ in anhydrous pyridine $(10 \mathrm{ml})$ was added chlorosulphonic acid $(1.0 \mathrm{ml})$ in anhydrous pyridine $(10 \mathrm{ml})$ with ice cooling and the solution was then heated overnight at $50^{\circ} \mathrm{C}$. The resulting solution was poured into ice water, acidified with concentrated $\mathrm{HCl}$, and extracted with $\mathrm{n}$-butanol. The organic layer was washed with $\mathrm{H}_{2} \mathrm{O}$, dried over anhydrous $\mathrm{Na}_{2} \mathrm{SO}_{4}$, mixed with a few drops of concentrated $\mathrm{NH}_{4} \mathrm{OH}$, and evaporated in vacuo. The residue was chromatographed on a silica gel column with ethanol:ammonium hydroxide $(9: 1 \mathrm{v} / \mathrm{v})$. The appropriate fractions were collected and evaporated, and the residue was crystalised from methanol-ethyl acetate to give $460 \mathrm{mg}$ of the ammonium salt of PABA-UDCA disulphate (melting point $177-183^{\circ} \mathrm{C}$ ); IRv $\mathrm{cm}^{-1}: 2920$, 2860, 1660, 1605, 1525; NMR (d $\mathrm{d}_{6}$ DMSO, $\delta$ ): $0.61(3 \mathrm{H}, \mathrm{s}), 0.89$ (3 H, s), 0.94 (3 H, d, J=6), 3.9 4.2 (2 H, m), 7.70 (2 H, d, J=9), $7 \cdot 87(2 \mathrm{H}$, $\mathrm{d}, \mathrm{J}=9), 10 \cdot 18(1 \mathrm{H}, \mathrm{s}))$. The ammonium salt was dissolved in $\mathrm{H}_{2} \mathrm{O}$, adjusted to $\mathrm{pH} 9.5$ with $\mathrm{NaOH}$, and passed through a column of ion exchange resin (Diaion HP 20, Mitsubishi Chemical Industries, Japan) to give the sodium salt of PABA-UDCA disulphate, which was used in the reported experiments. Figure 1 shows the chemical structures of PABA-UDCA disulphate and PABA-UDCA. The RFs of PABA-UDCA disulphate and its related compounds on thin layer chromatography (Kieselgel $60 \mathrm{~F}_{254}$ plates, Merck) with a solvent system of benzene: dioxane:methanol:acetic acid (15:5:3:2, v/v) were: UDCA, 0.91; PABA-UDCA, 0.87; PABA-UDCA disulphate, $0 \cdot 52$.

IN VITRO HYDROLYSIS OF PABA-UDCA DISULPHATE WITH CHOLYLGLYCINE HYDROLASE

Incubation of PABA-UDCA disulphate with cholyglycine hydrolase was carried out in accordance with the method described by Nair. Solutions with six different concentrations of PABA-UDCA disulphate were studied (A, B, C, $\mathrm{D}, \mathrm{E}$, and $\mathrm{F}$ respectively contained $2 \cdot 2 \mathrm{mg}$, 
<smiles>CC(CCC(=O)Nc1ccc(C(=O)O)cc1)C1CCC2C3C(O)CC4C[C@@H](O)CCC4(C)C3CCC12C</smiles>

Figure 1: Chemical structures of $P A B A-U D C A$ (where $R=$ $H$ ) and $P A B A-U D C A$ disulphate (where $R=S_{3} H$ ).

$1 \cdot 1 \mathrm{mg}, 0.55 \mathrm{mg}, 0.27 \mathrm{mg}, 0.14 \mathrm{mg}$, and $0.07 \mathrm{mg}$ of PABA-UDCA disulphate in each $2 \mathrm{ml}$ of reaction mixture $(1.489 \mathrm{mM}, 0.744 \mathrm{mM}, 0.372$ $\mathrm{mM}, 0.186 \mathrm{mM}, 0.093 \mathrm{mM}$, and 0.047 mM)). The amount of PABA released was estimated with an assay system for urinary PABA (Eisai Co, Tokyo, Japan). ${ }^{12}$

INCUBATION OF PABA-UDCA DISULPHATE WITH PANCREATIC ENZYMES AND HOMOGENATES OF INTESTINAL MUCOSA FROM RATS

These experiments were carried out by the method reported by Huijghebaert and Hofmann. ${ }^{13}$

CULTURE OF PABA-UDCA DISULPHATE WITH AEROBIC AND ANAEROBIC INTESTINAL BACTERIA This study was carried out as we described previously. ${ }^{8}$

ADMINISTRATION OF PABA-UDCA DISULPHATE TO RATS WITH DIFFERENT INTESTINAL BACTERIA An in vivo experiment was carried out with male Sprague-Dawley rats (weight range 200-300 g) as we previously reported. ${ }^{8}$ Rats were divided into a control group (group A), an antibiotic pretreated group (group B), and a bacterial overgrowth group (group C). Group B was further divided into three subgroups in accordance with the prescription and dose of antibiotics, as: group $\mathrm{B} 1,30000$ units polymixin $\mathrm{B}+$ $20 \mathrm{mg}$ tinidazole; group B2, $50 \mathrm{mg}$ kanamycin; group B3, $10 \mathrm{mg}$ clindamycin. Each group and subgroup consisted of 10 rats. Bacterial overgrowth rats were prepared in the same way as described previously. ${ }^{8}$ After oral administration of $15.0 \mathrm{mg}$ PABA-UDCA disulphate to each rat, the amounts of PABA excreted in a six hour urine sample were determined.

\section{EVERTED GUT SAC EXPERIMENTS}

Whether PABA-UDCA disulphate or PABAUDCA was actively absorbed from the small intestine was studied with an everted rat gut sac. Male Sprague-Dawley rats weighing about $250 \mathrm{~g}$ were fasted for 24 hours and killed by decapitation. Laparotomy was performed, and the intestine was flushed with $100 \mathrm{ml}$ of ice cold $0.9 \%$ $\mathrm{NaCl}$ solution. The entire small intestine was removed, and divided equally into four segments, (segments of jejunum I, jejunum II, ileum I, and ileum II from proximal to distal). The everted gut sac was prepared with $10 \mathrm{~cm}$ of small intestine from each segment in accordance with the method of Wilson and Wiseman. ${ }^{14}$ The sacs were filled with a modified Krebs-Ringer bicarbonate solution ( $\mathrm{pH} 7 \cdot 4$ ) containing $0 \cdot 1$ mM PABA-UDCA disulphate or PABA-UDCA. The composition of the Krebs-Ringer solution was: $128 \mathrm{mM} \mathrm{NaCl}, 1.2 \mathrm{mM} \mathrm{CaCl} 2,0.7 \mathrm{mM}$ $\mathrm{MgSO}_{4}, 5 \cdot 1 \mathrm{mM} \mathrm{KCl}, 1.3 \mathrm{mM} \mathrm{KH} \mathrm{PO}_{4}, 25 \cdot 6$ $\mathrm{mM} \mathrm{NaHCO}$, and $9 \mathrm{mM}$ glucose. The gut sacs were placed in incubation flasks containing $30 \mathrm{ml}$ of a similar solution to that of the serosal compartment. Under gentle oxygenation ( $95 \%$ $\mathrm{O}_{2}-5 \% \mathrm{CO}_{2}$ ), all flasks were incubated at $37^{\circ} \mathrm{C}$ for one hour. At the end of the incubation period, PABA-UDCA disulphate or PABA-UDCA concentration in the serosal and mucosal compartments was measured by the method of Bratton and Marshall after hydrolysis of PABA-UDCA disulphate or PABA-UDCA with $\mathrm{HCl} .^{15}$

\section{BILIARY RECOVERY OF PABA-UDCA AND ITS} DUSULPHATE IN RATS

Male Sprague-Dawley rats (weight range 200$300 \mathrm{~g}$ ) were fasted overnight before operation. Laparotomy was carried out under ether anesthesia and cannulation of the bile duct was performed for continuous bile collection. At the midpoint of the ileum, $0.020 \mathrm{mmol}$ of PABAUDCA disulphate $(15.0 \mathrm{mg})$ or PABA-UDCA $(10.0 \mathrm{mg})$ in a slightly basic (pH 7.5$)$ aqueous solution was injected into the lumen, and bile was collected for three hours. Biliary recovery of the compounds was calculated by subtracting the

TABLE I PABA-UDCA disulphate incubation test in patients with peritonitis

\begin{tabular}{|c|c|c|c|c|c|}
\hline Patient & Diagnosis & Operative procedure & $\begin{array}{l}\text { Total volume of } \\
\text { intraperitoneal pus } \\
\text { or fluid }(\mathrm{ml})\end{array}$ & $\begin{array}{l}\text { Result of PABA- } \\
\text { UDCA disulphate } \\
\text { incubation test }\end{array}$ & $\begin{array}{l}\text { Bacterial culture examination } \\
\text { of 'the sample }\end{array}$ \\
\hline A & $\begin{array}{l}\text { Perforation of duodenal } \\
\text { ulcer }\end{array}$ & Gastrectomy & 90 & $0 \mu \mathrm{g}$ & Negative \\
\hline B & $\begin{array}{l}\text { Ileocecal abscess due to } \\
\text { appendicitis }\end{array}$ & Appendectomy & 10 & $2.45 \mu \mathrm{g}$ & Negative \\
\hline C & Perforation of jejunum & $\begin{array}{l}\text { Partial resection of } \\
\text { jejunum }\end{array}$ & 1000 & $3.57 \mu \mathrm{g}$ & $\begin{array}{l}\text { Clostridium perfringens } \\
\text { Enterobacter aerogenes }\end{array}$ \\
\hline D & $\begin{array}{l}\text { Pericolic abscess due to } \\
\text { ischaemic colitis of the } \\
\text { sigmoid colon }\end{array}$ & Sigmoidectomy & 20 & $1.83 \mu \mathrm{g}$ & Streptococcus intermedius \\
\hline $\mathbf{E}$ & $\begin{array}{l}\text { Massive necrosis of the } \\
\text { jejunum and ileum } \\
\text { (thrombosis of superior } \\
\text { mesenteric artery) }\end{array}$ & $\begin{array}{l}\text { Massive resection of } \\
\text { the small intestine }\end{array}$ & 940 & $11 \cdot 11 \mu \mathrm{g}$ & $\mathbf{0}$ \\
\hline $\mathbf{F}$ & Radiation ileitis & Resection of ileum & 800 & $20.37 \mu g$ & $\begin{array}{l}\text { Bacteroides fragilis } \\
\text { Candida albicans }\end{array}$ \\
\hline
\end{tabular}

ॠValues express the amounts of PABA released by 30 minute incubation of PABA-UDCA disulphate with 1 ml of intraperitoneal pus or fluid. 


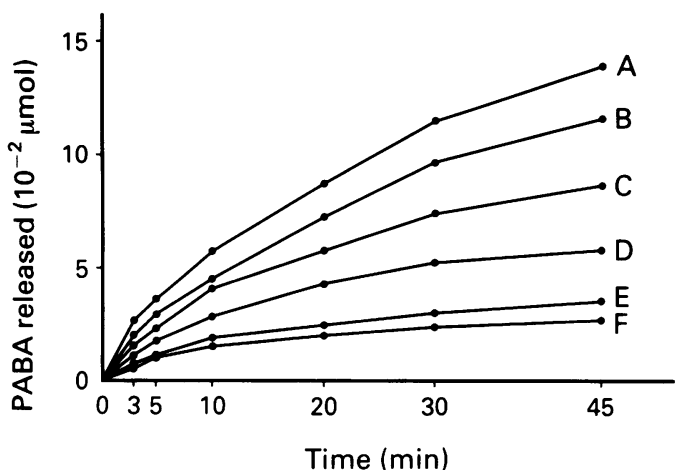

Figure 2: Time course of enzymatic hydrolysis of PABAUDCA disulphate by cholylglycine hydrolase. Incubation was carried out with six different concentrations: $A=1 \cdot 489$ $m M ; B=0.744 \mathrm{mM} ; C=0.372 \mathrm{mM} ; D=0.186 \mathrm{mM} ; E=$ $0.093 \mathrm{mM} ; F=0.047 \mathrm{mM}$ of PABA-UDCA disulphate.

amounts of biliary PABA measured without $\mathrm{HCl}$ hydrolysis from those with hydrolysis.

\section{INSTILLATION OF PABA INTO THE COLON IN} HUMANS

To investigate whether PABA was absorbed from the colon, an instillation was carried out in three patients. One of the patients (patient 1) had an obstructing tumour in the transverse colon with a loop colostomy in the caecum and two (patients 2 and 3) had obstructing tumours in the sigmoid colon with loop colostomy in the transverse colon. PABA ( $100 \mathrm{mg}$ ) dissolved in $20 \mathrm{ml}$ of saline solution was administered to the anal side of the colon through the colostomy, and urinary excretion of PABA was measured for six hours after instillation. Each one hour excretion of PABA after instillation was obtained by subtracting background PABA from a one hour urine sample before instillation.

INCUBATION OF PABA-UDCA DISULPHATE WITH INTRAPERITONEAL PUS OR FLUID FROM PATIENTS WITH PERITONITIS

To examine the magnitude of contamination of the peritoneal cavity by intestinal bacteria, an incubation of PABA-UDCA disulphate with intraperitoneal pus or fluid was carried out in six patients with localised or diffuse peritonitis

TABLE II Deconjugation of PABA-UDCA disulphate by aerobic bacteria

\begin{tabular}{llc}
\hline & $\begin{array}{l}\text { No of strains } \\
\text { capable of } \\
\text { deconjugation/ }\end{array}$ \\
& $\begin{array}{l}\text { No of strains } \\
\text { tested }\end{array}$ & $\begin{array}{l}\text { Deconjugation } \\
\text { ratio(\%) }\end{array}$ \\
Bacterium & $0 / 4$ & 0 \\
\hline Citrobacter freundii & $0 / 4$ & 0 \\
Enterobacter aerogenes & $6 / 6$ & 100 \\
Enterococcus faecalis & $0 / 5$ & 0 \\
Escherichia coli & $0 / 4$ & 0 \\
Klebsiella pneumoniae & $0 / 4$ & 0 \\
Klebsiella oxytoca & $1 / 1$ & 100 \\
Lactobacillus acidophilus & $0 / 4$ & 0 \\
Morganella morganii & $1 / 3$ & 33 \\
Protenu mirabilis & $0 / 4$ & 0 \\
Proteus vulgaris & $0 / 4$ & 0 \\
Pseudomonas aeruginosa & $0 / 4$ & 0 \\
Salmonella schwarzengrund & $0 / 4$ & 0 \\
Serratia marcescens & $0 / 4$ & 0 \\
Staphylococcus aureus & $4 / 4$ & 100 \\
Staphylococcus epidermidis & & \\
Methicillin resistant & $0 / 4$ & 0 \\
Staphylococcus aureus & $0 / 3$ & 0 \\
Vibrio parahaemolyticus & $0 / 3$ & 0 \\
Candida albicans & & \\
\hline
\end{tabular}

TABLE III Deconjugation of PABA-UDCA disulphate by anaerobic bacteria

\begin{tabular}{|c|c|c|}
\hline Bacterium & $\begin{array}{l}\text { No of strains } \\
\text { capable of } \\
\text { deconjugation/ } \\
\text { No of strains } \\
\text { tested }\end{array}$ & $\begin{array}{l}\text { Deconjugation } \\
\text { ratio(\%) }\end{array}$ \\
\hline \multicolumn{3}{|l|}{ Bacteroides: } \\
\hline bivius & $0 / 3$ & 0 \\
\hline fragilis & $4 / 7$ & 57 \\
\hline melanogenicus & $0 / 4$ & 0 \\
\hline thetaiotaomicron & $2 / 4$ & 50 \\
\hline vulgatus & $3 / 4$ & 75 \\
\hline \multicolumn{3}{|l|}{ Bifidobacterium: } \\
\hline adolescentis & $3 / 5$ & 60 \\
\hline longum & $3 / 4$ & 75 \\
\hline \multicolumn{3}{|l|}{ Clostridium: } \\
\hline difficile & $0 / 3$ & 0 \\
\hline perfringens & $7 / 7$ & 100 \\
\hline ramosum & $0 / 2$ & 0 \\
\hline \multicolumn{3}{|l|}{ Eubacterium: } \\
\hline aerofaciens & $3 / 6$ & 50 \\
\hline lentum & $0 / 4$ & 0 \\
\hline Fusobacterium varium & $1 / 4$ & 25 \\
\hline \multicolumn{3}{|l|}{$\begin{array}{l}\text { Peptostreptococcus: } \\
\text { anaerobius }\end{array}$} \\
\hline micros & $0 / 3$ & 0 \\
\hline Streptococcus intermedius & $0 / 3$ & 0 \\
\hline Veillonella parvula & $0 / 3$ & 0 \\
\hline
\end{tabular}

(Table 1). Intraperitoneal pus or fluid was obtained for bacterial culture examination and PABA-UDCA disulphate incubation test soon after laparotomy. The incubation test was done as follows: $0.4 \mathrm{ml}$ of $0.75 \%$ 2-mercaptoethanol and $0.4 \mathrm{ml}$ of $1.86 \%$ EDTA solutions in $1.0 \mathrm{ml}$ of $0.025 \mathrm{M}$ sodium acetate buffer $(\mathrm{pH} \mathrm{5.6)}$ were mixed with $2.0 \mathrm{mg}$ of PABA-UDCA disulphate. Then $0.6 \mathrm{ml}$ of intraperitoneal pus or fluid was added, and incubation was started at $37^{\circ} \mathrm{C}$ in a water bath. After 30 minutes the amount of PABA was determined with an assay system for urinary PABA. The amount of PABA was calculated by the subtraction of the amount of PABA obtained in the sample without incubation from that after a 30 minute incubation.

STATISTICAL ANALYSIS

Results are expressed as mean (SE). Statistical comparisons were made with Student's $t$ test for unpaired samples. A p value $<0.01$ was considered significant.

\section{Results}

HYDROLYSIS OF PABA-UDCA DISULPHATE BY CHOLYLGLYCINE HYDROLASE

Figure 2 shows the time course of enzymatic hydrolysis of PABA-UDCA disulphate at six different concentrations of substrate. The compound was efficiently hydrolysed by cholylglycine hydrolase. The $\mathrm{Km}$ value determined from the Lineweaver-Burk plot was 0.23 mM.

HYDROLYSIS OF PABA-UDCA DISULPHATE BY

PANCREATIC ENZYMES AND RODENT INTESTINAL MUCOSAL HOMOGENATES

PABA-UDCA disulphate was completely resistant to pancreatic enzymes such as pancreatin, carboxypeptidases $\mathrm{A}$ and $\mathrm{B}, \alpha$-chymotrypsin, and trypsin. Similarly it was not hydrolysed by mucosal homogenates from the small intestine of the rat. 


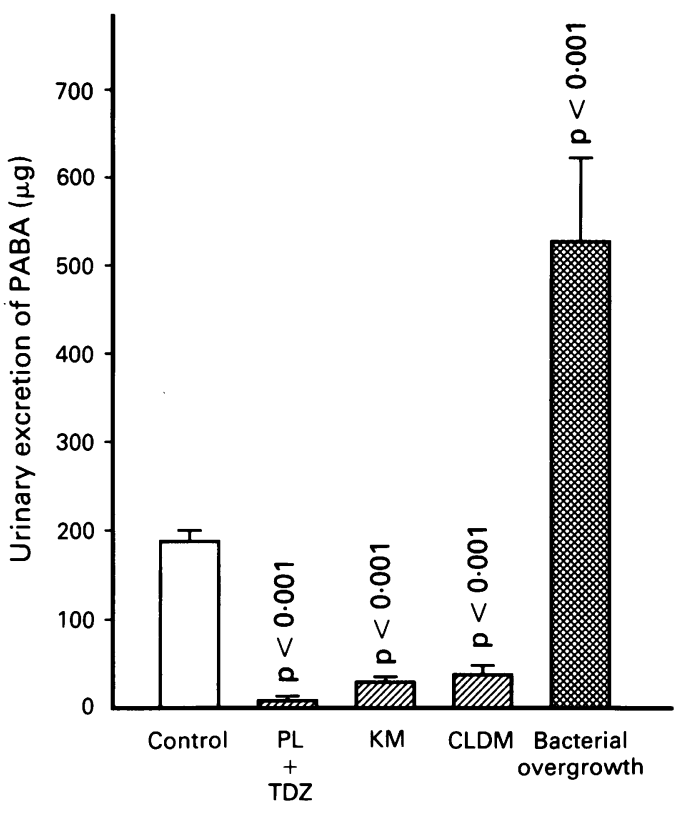

Figure 3: Cumulative urinary excretion of PABA (mean $(S E))$ during six hours after oral administration of $15 \mathrm{mg}$ $P A B A-U D C A$ disulphate to different groups of rats. $P L=$ polymixin $B ; T D Z=$ tinidazole $; K M=$ kanamycin $; C L D M=$ clindamycin.

\section{BACTERIAL DECONJUGATION}

Tables II and III show bacterial deconjugation data. Of the aerobic bacteria, only Enterococcus faecalis, Lactobacillus aciodophilus, Proteus mirabilis, and Staphylococcus epidermidis deconjugated PABA-UDCA disulphate.

By contrast, many anaerobic intestinal bacteria deconjugated this compound. These included Bacteroides fragilis, Bacteroides thetaiotaomicron, Bacteroides vulgatus, Bifidobacterium adolescentis, Bifidobacterium longum, Clostridium perfringens, Eubacterium aerofaciens, and Fusobacterium varium.

\section{ADMINISTRATION OF PABA-UDCA DISULPHATE IN} RATS

Figure 3 shows the results of the urinary excretion of PABA for six hours after dosing for all groups of rats. No adverse effects were noted in the rats and no deaths occurred. The control group of rats excreted (mean (SE)) $188.2(13.6)$ $\mu \mathrm{g}$ of PABA into urine. Significant $(\mathrm{p}<0.001)$

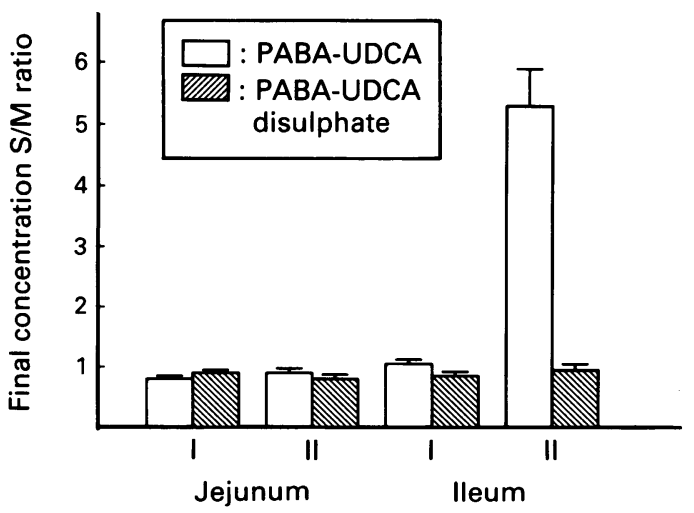

Figure 4: Final serosal/mucosal (s/m) concentration ratio in everted gut sac experiments of jejunum and ileum of rats with $P A B A-U D C A$ and PABA-UDCA disulphate.

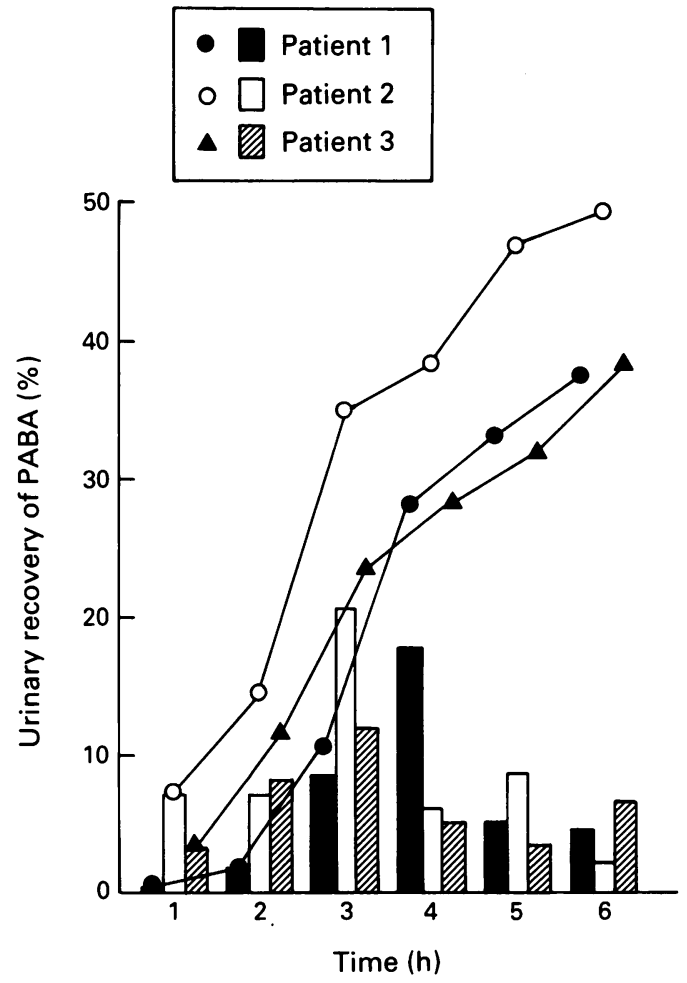

Figure 5: Urinary recovery of $P A B A$ and $P A B A$ instillation into the colon in humans. Lines express cumulative recovery of $P A B A$ into urine. Columns express fractional urinary recovery of $P A B A$.

suppressions of urinary PABA excretion were found in rats pretreated with antibiotics compared with the control group (B1, 4.9 (1.6) $\mu \mathrm{g}$; B2, $31.0(4 \cdot 7) \mu \mathrm{g} ; \mathrm{B} 3,40.9(5.5) \mu \mathrm{g})$. By contrast, rats with intestinal bacterial overgrowth had significantly greater excretion of PABA than the controls $(530 \cdot 1 \quad(30 \cdot 1) \mu \mathrm{g}$ $(\mathrm{p}<0.001))$.

\section{INTESTINAL ABSORPTION OF PABA-UDCA AND ITS} DISULPHATE

Figure 4 shows the results of the active transport experiment, indicating that PABA-UDCA was actively absorbed from the distal side of the ileum whereas its disulphate was not absorbed from any part of the small intestine. In vivo, considerable PABA-UDCA was recovered from bile $(32.6(1 \cdot 3) \%(n=3))$, whereas recovery of PABA-UDCA disulphate was poor $(1 \cdot 8(0 \cdot 2) \%$ $(\mathbf{n}=3))$, after intraileal instillation.

ABSORPTION OF PABA FROM THE COLON IN HUMANS Figure 5 shows urinary recovery of PABA after intracolonic instillation of PABA in human subjects. The maximal urinary excretion of PABA was found three or four hours after PABA instillation. Total recoveries of PABA during six hours after instillation were $37 \cdot 7 \%, 49 \cdot 5 \%$, and $38.5 \%$ in patients 1,2 , and 3 respectively.

PABA-UDCA DISULPHATE INCUBATION TEST IN PATIENTS WITH PERITONITIS

PABA-UDCA disulphate was easily soluble in assay solution with $\mathrm{pH} 5.6$ sodium acetate buffer, whereas the maximal solubility of PABA- 
UDCA in that solution was $1 \cdot 2 \mu \mathrm{g} / \mathrm{ml}$. The incubation data were obtained within 90 minutes after starting the test. Table I shows the results. The amounts of PABA that were released by 30 minute incubation with $1 \mathrm{ml}$ of the sample were $0 \mu \mathrm{g}, 2.45 \mu \mathrm{g}, 3.57 \mu \mathrm{g}, 1.83 \mu \mathrm{g}, 11.11 \mu \mathrm{g}$, and $20.37 \mu \mathrm{g}$ for patients $\mathrm{A}, \mathrm{B}, \mathrm{C}, \mathrm{D}, \mathrm{E}$, and $\mathrm{F}$ respectively. Therefore the abilities of the whole intraperitoneal fluids to deconjugate PABAUDCA disulphate were calculated as $0 \mathrm{mg}, 0.02$ $\mathrm{mg}, 3.57 \mathrm{mg}, 0.04 \mathrm{mg}, 10.44 \mathrm{mg}$, and $16.30 \mathrm{mg}$ in the respective patients. Patients $B$ and $E$ were positive in the test but were negative in bacterial culture examination of the sample. In patients $C$, $E$, and $F$ with high values in the test it was difficult to control the infection and they died on the second, 134th, and 95th day after operation respectively.

\section{Discussion}

For a simple evaluation of intestinal bacteria we previously reported reliable results in animals with a PABA-UDCA test involving oral administration of PABA-UDCA which contains $p$ aminobenzoic acid (PABA) as a tracer group. ${ }^{89}$ The principle behind the test is as follows: the compound, a condensation product of UDCA with PABA, releases PABA when bacterial cholyglycine hydrolase is present in the gut. Free PABA is rapidly absorbed and excreted in the urine, so that the urinary excretion of PABA reflects the activity of intestinal bacteria.

In our present study, a disulphated derivative of PABA-UDCA was synthesised and its basic characters were investigated. This compound, PABA-UDCA disulphate, features in common with PABA-UDCA: Firstly, it was efficiently hydrolysed by cholyglycine hydrolase. Secondly, all the microorganisms that deconjugate PABA-UDCA or glycocholic acid split PABA-UDCA disulphate resulting in the release of free PABA. Thirdly, the amounts of PABA excreted in urine during six hours after dosing were significantly lower in rats pretreated with antibiotics and higher in bacterial overgrowth rats compared with controls, as found in the PABA-UDCA administration test. There were, however, some differences between PABAUDCA and its disulphate. Firstly, $\mathrm{Km}$ values were different. PABA-UDCA disulphate had a lower $\mathrm{Km}$ value $(0.23 \mathrm{mM})$ compared with PABA-UDCA $(3.71 \mathrm{mM})$. Therefore, the sulphated compound might be more sensitive to cholyglycine hydrolase than PABA-UDCA. The second difference was in intestinal absorption. PABA-UDCA, similar bile acids conjugated to glycine or taurine, was actively absorbed from the distal ileum and recovered efficiently from bile. This means that PABA-UDCA that is not hydrolysed by bacterial enzymes in the small intestine is efficiently absorbed from the terminal ileum by active transport. Therefore it is possible to speculate that the PABA-UDCA administration test reflects the activity of bacteria in the small intestine when it is given orally in lower doses than the maximal amount absorbed from the terminal ileum.

Sulphated bile acids are excreted in urine in large amounts under cholestatic conditions. ${ }^{1617}$
These sulphate esters of bile acids are usually less toxic than their unesterified parent substances ${ }^{18}$ and are eliminated more rapidly through faeces and urine so that the organism can be efficiently detoxified in the case of cholestasis. ${ }^{19-23}$ Lack et $a l^{24}$ and Walker et $a l^{25}$ reported that bile acid sulphates were absorbed from the intestine to a lesser extent than their unesterified parent substances. Likewise the disulphate ester of PABAUDCA was not actively absorbed from any part of the small intestine, and was recovered from bile in only small amounts in our experiment.

Eyssen et al,,$^{26}$ Huijghebaert et al, ${ }^{27}$ and Pacini et $a l^{28}$ previously confirmed the absence of bacterial desulphating activity on 7-monosulphate esters of bile acids but the presence of such desulphating activity on 3-monosulphate esters in cultures of faeces from humans, rats, and mice. Consequently, even if the disulphate ester of PABA-UDCA is desulphated at the $3 \alpha$ position by bacterial action after oral administration the $7 \beta$-monosulphate ester of PABA-UDCA formed can be resistant to bacterial transformation resulting in no absorption from the gut and rapid excretion into faeces. Therefore PABA-UDCA disulphate can be a single pass type of substance in the gut. Contrary to our expectations, PABA that was instilled into the human colon was recovered well from urine. This means that there is a good absorption of PABA from the colon. For these reasons, we can deduce that PABAUDCA disulphate is a single pass type of compound in the gut for the evaluation of intestinal microflora, and the administration test results reflect the sum of activities of bacteria in the small intestine and colon. Practically, the oral administration test with PABA-UDCA disulphate makes possible the evaluation of colonic bacteria because most intestinal bacteria is present in the colon. ${ }^{29}$ Also, the test may be useful for monitoring the effects of antibiotics on the gastrointestinal bacteria.

The third difference is in the solubility of the compounds in water. PABA-UDCA was practically insoluble in the assay solution containing 2mercaptoethanl, EDTA, and $\mathrm{pH} 5.6$ sodium acetate buffer. It was rendered easily soluble in it, however, by the introduction of sulphate groups on the $3 \alpha$ and $7 \beta$ hydroxyl groups of PABA-UDCA. This increase in water solubility made possible an in vitro incubation test with intraperitoneal pus or fluid from patients with peritonitis. Positive results in this incubation test indicate the intraperitoneal presence of cholyglycine hydrolase, namely intraperitoneal leakage of intestinal bacteria. Data obtained from the test reflect the magnitude of intraperitoneal contamination by intestinal bacteria. Considered from the standpoints of bacterial peritonitis and prediction of prognosis, it is important to know how much the patients with peritonitis are contaminated by intestinal bacteria. We consider that this PABA-UDCA disulphate incubation test makes it possible to express the severity of bacterial peritonitis quantitatively within 90 minutes.

Intestinal bacteria are still difficult to assess due to the complexity and expense of measurement of intestinal microorganisms. The PABAUDCA disulphate described in this article might 
be a material to improve this situation. Further studies should be done on humans.

1 Fromm H, Hofmann AF. Breath test for altered bile-acid metabolism. Lancet 1971; ii: 621-5.

2 Sherr HP, Sasaki Y, Newman A. Detection of bacterial deconjungation of bile salts by a convenient breath analysis technique. N Engl f Med 1971; 285: 656-61.

3 Thaysen EH. Diagnostic value of the ${ }^{14} \mathrm{C}$-cholyglycine breath test. Clin Gastroenterol 1977; 6: 227-45.

4 King CW, Toskes PP, Spivey JC, Lorenz E, Welkos SL. Detection of small intestine bacterial overgrowth by means of ${ }^{14} \mathrm{C}$-D-xylose breath test. Gastroenterology $1979 ; 77: 75-$ 82 .

5 King CE, Toskes PP, Guilarte TR, Lorenz E, Welkos SL. Comparison of the one-gram $\mathrm{D}-\left({ }^{14} \mathrm{C}\right)$ xylose breath test to the $\left({ }^{14} \mathrm{C}\right)$ bile acid breath test in patients with small-intestine bacterial overgrowth. Dig Dis Sci 1980; 25: 53-8.

6 Metz G, Gassull MA, Drasar BS, Jenkins DJA, Blendis LM Breath-hydrogen test for small intestinal bacterial colonisation. Lancet 1976; i: 668-9.

7 Rhodes JM, Middleton P, Jewell DP. The lactulose hydrogen breath test as a diagnostic test for small-bowel bacterial overgrowth. Scand $\mathcal{F}$ Gastroenterol 1979; 14: 333-6.

8 Takahashi M, Maeda Y, Tashiro H, Eto T, Goto T, Sanada O. A new simple test for evaluation of intestinal bacteria. World A Surg 1990; 14: 628-35.

9 Takahashi M, Maeda Y, Tashiro H, Akazawa F, Okajima M Yoshioka S, et al. Basic studies on ursodeoxycholyl-paraaminobenzoic acid for evaluation of intestinal microflora. Scand F Gastroenterol 1991; 26: 577-88.

10 Goto J, Kato H, Hasegawa F, Nambara T. Synthesis of monosulfates of unconjugated and conjugated bile acids. Chem Pharm Bull 1979; 27: 1402-11.

11 Nair PP. Enzymatic cleavage of bile acid conjugates. In: Schiff L, Carey TB, Dietschy JR, Dietschy JM, eds. Bile salt metabolism. Springfield Ill: CC Thomas, 1969: 172-83.

12 Yamato C, Kinoshita K. A simple assay for measurement of urinary p-aminobenzoic acid in the oral pancreatic function test. Anal Biochem 1979; 98: 13-7.

13 Huijghebaert SM, Hofmann AF. Pancreatic carboxypeptidase hydrolysis of bile acid-amino acid conjugates: selective resistance of glycine and taurine amidates. Gastroenterology 1986; 90 : 306-15.

14 Wilson TH, Wiseman GH. The use of sacs of everted small intestine for the study of transference of substances from the mucosal to serosal surface. $\mathcal{F}$ Physiol 1954; 123: 116-25.

15 Bratton AC, Marshall EK. A new coupling compound for sulfanilamide determination. $\mathcal{F}$ Biol Chem 1939; 128: $537-$ 50

16 Makino I, Shinozaki K, Nakagawa S. Measurement of sulfated and nonsulfated bile acids in urine, serum, and bile of patients with hepatobiliary disease. Gastroenterology 1975 68: 545-53.

17 Almé B, Bremmelgaard A, Siövall J, Thomassen P. Analysis of metabolic profiles of bile acids in urine using a lipophilic anion exchanger and computerized gas-liquid chromatoanion exchanger and computerized gas-liquid chroma

18 sriehl A mass spectrometry. F Lipid Res 1977; 18: 339-62. Rotthauwe HW, Senn M. Bile acids and their sulfated and Rotthauwe HW, Senn $M$. Bile acids and their sulfated and
glucuronidated derivatives in bile, plasma, and urine of glucuronidated derivatives in bile, plasma, and urine of barbital treatment. Eur f Clin Invest 1980; 10: 307-16.

19 Low-Beer TS, Tyor MP, Lack L. Effect of sulphation of taurolithocholic acid and glycolithocholic acid on their intestinal transport. Gastroenterology 1969; 56: 721-6.

20 Cowen AE, Korman MG, Hofmann AF, Cass OW. Metabolism of lithocholate in healthy man. I. Biotransformation and biliary excretion of intravenously administered lithocholate, lithocholylglycine, and their sulfates. Gastroenterology 1975; 69: 59-66.

21 Cowen AE, Korman MG, Hofmann AF, Cass OW, Coffin SB Cowen AE, Korman MG, Hofmann AF, Cass OW, Coffin SB. hepatic circulation. Gastroenterology 1975; 69: 67-76.

22 Cowen AE, Korman MG, Hofmann AF, Thomas PJ. Metabolism of lithocholate in healthy man. III. Plasma disappearance of radioactivity after intravenous injection of labeled lithocholate and its derivatives. Gastroenterology 1975; 69: 77-82.

23 Back P, Gerok W. Differences in renal excretion between glyco-, tauroconjugates, sulfoconjugates and glucuronconjugates of bile acids in cholestasis. In: Paumgartner $G$, Stieh $A$ eds. Bile acid metabolism in health and disease. Lancaster: MTP Press, 1977: 93-100.

24 Lack L, Weiner IM. Intestinal bile salt transport: structureactivity relationships and other properties. Am $\mathcal{F}$ Physio activity relationships

25 Walker S, Stiehl A, Raedsch R, Klöters P, Kommerell B Colonic absorption of sulfated and nonsulfated bile acids in rat. Digestion 1986; 33: 184-9.

26 Eyssen H, Parmentier G, Mertens J. Sulfated bile acids in germ-free and conventional mice. Eur $\mathcal{F}$ Biochem 1976; 66 ; 507-14.

27 Huijghebaert S, Parmentier G, Eyssen H. Specificity of bile salt sulfatase activity in man, mouse and rat intestinal microflora. I Steroid Biochem 1984; 20: 907-12.

28 Pacini N, Albini E, Ferrari A, Zanchi R, Marca G, Bandiera T. Transformation of sulfated bile acids by human intestina microflora. Drug Research 1987; 37: 983-7.

29 Drasar BS, Barrow PA. The bacterial flora of the normal intestine. In: Drasar BS, Barrow PA, eds. Aspects of microbiology. Vol 10. Intestinal microbiology. Berkshire: Van Nostrand Reinhold (UK), 1985: 19-41. 